Опанасюк Ірина

кандидат психологічних наук, психолог ліцею №12 імені Івана Франка м. Івано-Франківськ https://orcid.org/0000-0003-3626-0691

DOI https://doi.org/10.35619/praprv.v1i16.222

\title{
ПРОГРАМА РОЗВИТКУ ЕQ СТАРШОКЛАСНИКІВ АРТ-ТЕРАПЕВТИЧНИМИ ТА ДОПОМІЖНИМИ ЗАСОБАМИ
}

У статті представлено авторську програму розвитку EQ старшокласників арттерапевтичними та допоміжними засобами, спрямовану на рефлексивне осмислення суб'єктом емоційного змісту своӥх та інших учасників світоглядно-диспозиційних пошуків, виражених у художньо-символічних формах арт-терапевтичних та інших експресивноінтерактивних засобів, спрямованого на конструктивну регуляцію изього змісту. Викладено методичне забезпечення, прочедуру i результати емпіричної складової дослідження, спрямованої на діагностування якостей, які пов'язані з емочійним інтелектом, з метою створення емпіричної основи формувального експерименту. Наведено результати експериментального дослідження щзодо запропонованої програми.

Ключові слова: старший шкільний вік, емоційний інтелект, емоційні переживання, арттерапія, художньо-символічне самовираження, рефлексивне осмислення проблемних дихотомій «хочу-можу».

Постановка проблеми. Розвиток емоційного інтелекту підростаючих поколінь $\epsilon$ актуальною психолого-педагогічною проблемою. Найбільшої значущості ця проблема набуває у старшому шкільному віці, коли формуються змістові основи спрямованості особистості посередництвом iї рефлексивного ціннісно-орієнтаційного самовизначення, вирішально визначальним фактором якого $\epsilon$ емоційні переживання. Вочевидь, що цей процес забезпечується емоційним інтелектом.

Мета дослідження - розробити та апробувати програму розвитку емоційного інтелекту старшокласників арт-терапевтичними та допоміжними засобами.

Методологічне й методичне обгрунтування концепції EQ покладено в наукові доробки вітчизняних (Власов, Коврига, Носенко, Саннікова, Симоненко, Чебикін) і зарубіжних учених (Андрєєва, Бар-Он, Гарднер, Гарскова, Гоулман, Ізард, Ільїн, Карузо, Люсін, Маєр, Манойлова, Прихожан, Саловей та ін.). Порівняльний аналіз дослідниками дефінітивних характеристик емоційного інтелекту дозволяє нам представити своє бачення основного психологічного змісту цього феномена, розроблене на основі визначення інтелекту, яке запропонував (Москалець, 2014). За нашим розумінням, емоційний інтелект - пізнавальна спроможність людини, котра являє собою здатність виявляти ті емоційні складові соціальних об'єктів, способи їх використання і впливу на них, які забезпечують вирішення емоційно забарвлених проблем, розв'язання задач на основі розуміння суб'єктом власних емоційних переживань та емоційних процесів і станів інших людей (когнітивна та предикативна емпатія) як факторів мотивації та безпосередніх спонук вчинків, поведінки.

У старшому шкільному віці формується змістовий базис спрямованості особистості (ціннісних орієнтацій, переконань, світогляду, віри, диспозицій) посередництвом іiі рефлексивного аксіологічного (ціннісно-орієнтаційного) самовизначення. Перспективи й плани щодо майбутнього дорослого життя утворюють «афективний центр» (Божович, 1972) у психіці старшокласника, навколо якого починають «обертатись» усі його інтереси, вчинки, діяльність. Розширюється коло емоційно забарвлених предметів і поглиблюються вектори їх осмислення (інтелектуального опрацювання). Істотно підвищити ефективність цих вельми значущих 
формувальних процесів може i має обгрунтований розвиток емоційного інтелекту старшокласників.

Враховуючи психофізіологічні особливості підлітків, виникла необхідність впровадження розвивально-корекційних технологій, які базуються на використанні «мови» візуальної пластичної експресії. Методологічним принципом організації розвивальнокорекційного впливу на особистість $є$ визнання того що «психіка людини $є$ складним, нелінійним, відкритим механізмом, а отже нав'язати ій шляхи розвитку практично неможливо, можна лише сприяти іï розвитку та саморозвитку» (Вайбах, \& Дакс, 1998). Це стосується безумовно і емоційного інтелекту, як складного психічного феномену особистості, розвиток якого передбачає використання арсеналу методів. На нашу думку, одним з найефективніших засобів розвитку емоційного інтелекту є техніки арт-терапії.

Спираючись на наукові дослідження 3 розвитку емоційного інтелекту особистості (Девідсон, \& Беглі, 2012; Конопкін, 2006; Саєнко, 2010), техніки арт-терапії (Бабенко, 2007; Грегг, 2003; Копитін, 2005; Остер, \& Гоулд, 2000; Терлецька, 2007; Чернуха, 2010; Яценко, \& Теслюк, 2005), закономірності впливу навчально-виховного процесу на розвиток особистості (Калошин, \& Безносюк, \& Лемешко, 2006; Лібін, 2000) та власні результати експериментального вивчення феномену (Опанасюк, 2014; 2015; 2015) ми запропонували реалізацію формувально-експериментальної програми (табл.1), як комплексного засобу формування емоційного інтелекту у старшокласників засобами арт-терапії. Вік респондентів: 15-17 років.

Мета програми - розвиток емоційного інтелекту старшокласників шляхом рефлексивного осмислення ними емоційного змісту своїх та інших учасників проблемних дихотомій «хочу - маю», «прагну - можу», виражених у художньо-символічних формах арттерапевтичних та інших експресивно-інтерактивних засобів, спрямованого на конструктивну регуляцію цього змісту у бік сприяння бажаному.

Вагомою складовою програми став тренінг розвитку емоційного інтелекту старшокласників, спрямований на оволодіння техніками міжособистісного спілкування (Степанов, 2006). Він передбачає навчання, формування та розвиток особистості. Це дає можливість зрозуміти, що сфера застосування тренінгу не обмежується розвитком навичок ефективного спілкування і підвищення комунікативної компетенції, а передбачає можливості розвитку всіх психічних структур особистості в цілому.

Тренінг виступає «синтетичною антропотехнікою» (Лібін, 2000) потенційних можливостей особистості у простір перспектив як професійної, так і виключно особистісної реалізації. Процес так званого перетворення відбувається за умови реалізації функціонального змісту тренінгу, психологічної корекції, психологічної терапії та розвивального навчання. Психологічний корекційний зміст тренінгу полягає в цілеспрямованому психологічному впливі на ті чи інші психологічні структури індивіда, з метою забезпечення повноцінного розвитку i функціонування його особистості (Остер, \& Гоулд, (2000).

Розроблена нами формувально-експериментальна програма своїм структурним змістом передбачає реалізацію 4 розвивальних блоків:

1) блок розуміння власних емоцій. Очікуваний результат - розвиток здатності рефлексивно осмислювати власні емоційні переживання та їх причини.

2) блок управління та саморегуляції емоцій. Очікуваний результат - розвиток вміння регулювати власні емоції та управляти ними.

3) блок розуміння емоцій інших. Очікуваний результат - розвиток здатності адекватно сприймати, ідентифікувати, розуміти емоційні стани інших і реагувати на них.

4) блок конструктивного впливу на емоції інших. Очікуваний результат - розвиток навичок конструктивного впливу на емоційні реакції, процеси і стани інших.

Визначення змістових блоків здійснювалось на дотриманні загальних правил побудови тренінгових занять. Створена програма є сукупністю технологій індивідуальної та групової психологічної роботи, що репрезентує інтегрований підхід, у рамках якого здійснювалась робота як із старшокласниками, так із їхнім оточенням і спрямована на набуття знань про емоційні феномени та про їх регуляцію; формування вмінь i навичок комунікативно 
компетентної експресії власних емоцій та керування ними; розвиток здатності розуміти і конструктивно впливати на емоційні переживання комунікантів, налагоджувати і підтримувати ефективну взаємодію.

Тому, ефективними допоміжними засобами розвитку емоційного інтелекту учнів старших класів виявились: 1) батьківський лекторій у форматі загальних батьківських зборів; 2) лекції для педагогічного колективу школи-експериментального майданчика; 3) психологопедагогічні консультації для батьків та педагогів; 4) запропоновані учням, їхнім батькам та педагогам книги й кінофільми 3 розвивальним, щодо емоційного інтелекту, змістом; 5) щоденник інтелектуальної рефлексії своїх емоційних переживань; 6) індивідуальне консультування досліджуваних, їхніх батьків та педагогів експериментатором-тренером.

Розвиток емоційного інтелекту школяра (у нашому випадку старшокласника) пов'язується із рівнем розвитку емоційного інтелекту батьків, вчителів, які покликані забезпечити конструктивний простір взаємодії, становлення особистості, бо «тільки особистість може виховати особистість» (Юнг). Звідси безперервна освіта школяра й наставників виховного процесу сприятиме усій «поліфонії привнесень» у розвиток емоційного інтелекту й особистості старшокласника.

Вважаємо за необхідне представити авторську програму розвитку EQ старшокласників арт-терапевтичними і допоміжними засобами (див. табл. 1), чітко означуючи тематику сесій, мету і зміст кожної сесії.

Таблиия 1

\section{Формувально-ексиериментальна програма} «Розвиток емоційного інтелекту стариокласників засобами арт-терапї̈»

\begin{tabular}{|c|c|}
\hline Теми та мета сесії & Зміст сесії \\
\hline \multicolumn{2}{|c|}{ Заняття 1. Емоиійний інтелект як особистісна складова } \\
\hline $\begin{array}{l}\text { Вступна частина. Ознайомлення } \\
\text { учасників із метою та завданнями } \\
\text { роботи в корекційній групі, правилами } \\
\text { роботи в ній; з'ясування очікувань } \\
\text { школярів щодо тренінгу та окреслення } \\
\text { основних стратегій і тактик корекційно- } \\
\text { розвивальної програми; виялення } \\
\text { труднощів та бар'єрів в міжособистісної } \\
\text { взаємодії. Ознайомлення учасників з } \\
\text { темою тренінгу; сприяння розвитку у } \\
\text { них вмінь розпізнавати та } \\
\text { усвідомлювати власні емоційні стани. }\end{array}$ & $\begin{array}{l}\text { Вступне слово. } \\
\text { Знайомство. } \\
\text { Правила. } \\
\text { Очікування. } \\
\text { Міні-лекція «Емоційний інтелект як особистісна } \\
\text { складова». } \\
\text { Вправа «Мої емоції». } \\
\text { Вправа «Кольорова гама». } \\
\text { Релаксаційна вправа «Судно на якому я пливу». } \\
\text { Обговорення учасниками отриманого на занятті } \\
\text { досвіду. } \\
\text { Домашнє завдання. }\end{array}$ \\
\hline \multicolumn{2}{|c|}{ Заняття 2. Усвідомлення емочій через тілесні відчуття } \\
\hline $\begin{array}{l}\text { Пізнання старшокласниками } \\
\text { емоційних стайх } \\
\text { ділитися своїми почуттями. Вираження } \\
\text { емоцій за допомогою невербального } \\
\text { способу; усвідомлення особливостей } \\
\text { власних емоцій. } \\
\text { Розвиток навичок рефлексії. }\end{array}$ & $\begin{array}{l}\text { Вступне слово. } \\
\text { Вправи для згуртування групи та розвитку } \\
\text { емоційно-вольової сфери. Очікування. } \\
\text { Міні-лекція «Усвідомлення емоцій через тілесні } \\
\text { відчуття». } \\
\text { Вправа «Позитивні та негативні емоції в моєму } \\
\text { житті». } \\
\text { Вправа «Міміка і стан людини». } \\
\text { Релаксаційна вправа «Галявина». } \\
\text { Обговорення учасниками отриманого на занятті } \\
\text { досвіду. Домашнє завдання. }\end{array}$ \\
\hline
\end{tabular}


Пізнання особливостей негативних й позитивних емоцій; розуміння емоційних привнесень у власне особисте життя учнів; розвиток емоційно-вольової сфери. Диференціація й усвідомлення причин виникнення емоцій та почуттів в різних ситуаціях.
Вступне слово.

Вправи для згуртування групи та розвитку емоційно-вольової сфери.

Очікування.

Міні-лекція «Диференціація й усвідомлення власних емоцій».

Вправа «Дорога мого життя: минуле, теперішнє, майбутнє».

Вправа «Чарівний базар».

Вправа «Я спокійний».

Музична вправа.

Обговорення учасниками отриманого на занятті досвіду. Домашнє завдання.

\section{Заняття 4. Вербальне і невербальне вираження емоцій}

Розвиток особливостей до розуміння експресії; формування навичок в розвитку вербалізації почуттів; усвідомлення неузгодженостей між вербальним й невербальним вираженням емоцій.

Розвиток здатності до емоційного переживання інших.
Вступне слово.

Вправи для згуртування групи та розвитку емоційно-вольової сфери.

Очікування.

Лекція «Вербальне i невербальне вираження емоцій».

Групова вправа «Мій внутрішній стан».

Вправа «Приміряння ролей».

Танець «Морські хвилі».

Обговорення учасниками отриманого на занятті досвіду.Домашнє завдання.

\section{Заняття 5. Емоиійне реагування}

Усвідомлення необхідності поваги один до одного й розуміння свого емоційного стану; пізнання іншого через тактильні відчуття; зняття тілесної напруги. Розвиток навичок емоційного реагування; виявлення своїх сильних й слабких сторін 3 різних позицій.

Вступне слово.

Вправи для згуртування групи та розвитку емоційно-вольової сфери.

Очікування.

Міні-лекція «Емоційне реагування».

Вправа «Як я бачу сам себе?, Як мене бачать люди?»

Вправа «Зніми втому»ю

Танець «Почуття та емоції: радість, страх, сум...»

Обговорення учасниками отриманого на занятті досвіду. Домашнє завдання.

Заняття 6. Способи саморегуляиії емоичійного стану

Оволодіння навичками саморегуляції власного емоційного стану; розвиток здатності відчувати іншого учасника й передбачати його дії. Усвідомлення причин власного страху й невпевненості за допомогою кольору. Подолання в'ялості, сонливості, втоми й мобілізація уваги; зняття емоційної та фізичної напруги.
Вступне слово.

Вправи для згуртування групи та розвитку емоційно-вольової сфери.

Очікування.

Міні-лекція «Способи саморегуляції емоційного стану».

Вправа «Я в стані спокою, страху й після страху». Вправа «Мобілізуюче дихання».

Вправа «Заспокійливе дихання». 


\begin{tabular}{|c|c|}
\hline & $\begin{array}{l}\text { Музична вправа. } \\
\text { Обговорення учасниками отриманого на занятті } \\
\text { досвіду. Домашнє завдання. }\end{array}$ \\
\hline \multicolumn{2}{|c|}{ Заняття 7. Самоконтроль та саморегуляція емоцій } \\
\hline $\begin{array}{l}\text { Ознайомлення із способами } \\
\text { управління своїми емоціями; вміння } \\
\text { розпізнавати емоційний стан іншого } \\
\text { та налагоджувати } \\
\text { взаємодію. Вміннявну } \\
\text { свої писловлювати } \\
\text { невдоволення, образ й прийняття } \\
\text { емоцій інших; розвиток навичок } \\
\text { управління агресією. }\end{array}$ & $\begin{array}{l}\text { Вступне слово. } \\
\text { Вправи для згуртування групи та розвитку } \\
\text { емоційно-вольової сфери. } \\
\text { Очікування. } \\
\text { Міні-лекція «Управління власними емоціями». } \\
\text { Колажі «Стосунки та емоції»; «Вибух емоцій». } \\
\text { Вправа «Я-повідомлення». } \\
\text { Релаксаційна вправа «Кольоровий дощ». } \\
\text { Обговорення учасниками отриманого на занятті } \\
\text { досвіду. Домашнє завдання. }\end{array}$ \\
\hline \multicolumn{2}{|c|}{ Заняття 8. Самоконтроль та саморегулящџія емочій } \\
\hline 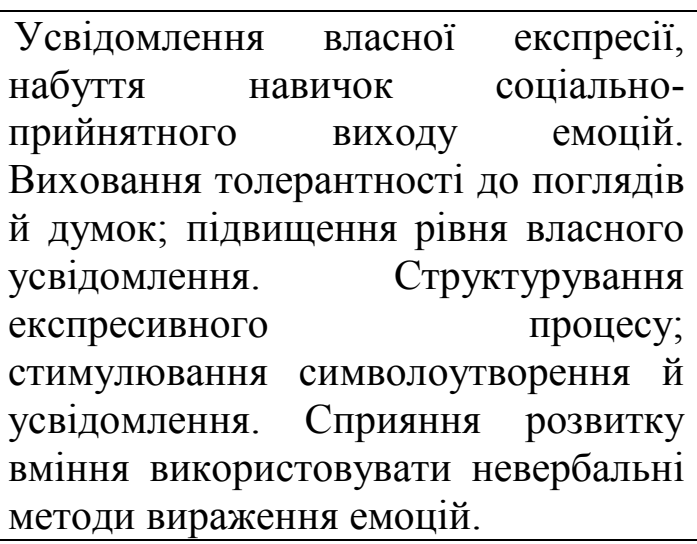 & $\begin{array}{l}\text { Вступне слово } \\
\text { Вправи для згуртування групи та розвитку } \\
\text { емоційно-вольової сфери } \\
\text { Очікування } \\
\text { Міні-лекція «Управління власними емоційними } \\
\text { проявами» } \\
\text { Колажі «Мій настрій»; «Війна емоцій» } \\
\text { Вправа «Зобрази прислів’я» } \\
\text { Музична вправа } \\
\text { Обговорення учасниками отриманого на занятті } \\
\text { досвіду. Домашнє завдання. }\end{array}$ \\
\hline \multicolumn{2}{|c|}{ Заняття 9. Розпізнавання та ідентифікаиія чужих емоиій } \\
\hline $\begin{array}{l}\text { Отримання різнобічних уявлень про } \\
\text { емоційні переживання інших людей; } \\
\text { формування позитивного ставлення } \\
\text { до себе й до інших. Розпізнавання й } \\
\text { розуміння проявів емоцій інших; } \\
\text { отримання позитивного досвіду рухів } \\
\text { та наповнення тіла енергією через } \\
\text { спонтанне самовираження. }\end{array}$ & $\begin{array}{l}\text { Вступне слово. } \\
\text { Вправи для згуртування групи та розвитку } \\
\text { емоційно-вольової сфери. } \\
\text { Очікування. } \\
\text { Міні-лекція «Усвідомлення та розуміння чужих } \\
\text { емоцій». } \\
\text { Вправа «Фантом». } \\
\text { Вправа «Емоції в картинках». } \\
\text { Вправа «Рефлексивне слухання». } \\
\text { Танець «Гроза». } \\
\text { Обговорення учасниками отриманого на занятті } \\
\text { досвіду. Домашнє завдання. }\end{array}$ \\
\hline \multicolumn{2}{|c|}{ Заняття 10. Розуміння чужих емочій } \\
\hline $\begin{array}{l}\text { Розвиток спостережливості до } \\
\text { експресивних проявів оточуючих; } \\
\text { можливості впливу на емоційний } \\
\text { стан інших. Створення певного } \\
\text { образу й розуміння зв’язку свого } \\
\text { емоційного стану } 3 \text { тілесними }\end{array}$ & $\begin{array}{l}\text { Вступне слово. } \\
\text { Вправи для згуртування групи та розвитку } \\
\text { емоційно-вольової сфери. } \\
\text { Очікування. } \\
\begin{array}{l}\text { Міні-лекція «Усвідомлення емоційних проявів } \\
\text { чужих емоцій». }\end{array}\end{array}$ \\
\hline
\end{tabular}




\begin{tabular}{|c|c|}
\hline \begin{tabular}{lcr} 
відчуттями; & \multicolumn{3}{c}{ віднаходження } \\
внутрішніх & ресурсів, як рушіїв \\
розвитку і взаємодії & оточенням. \\
Розвиток & вмінь & ефективної \\
соціально-психологічної взаємодії в \\
групі; розуміння міміки та її значення \\
в процесі спілкування; зняття стану \\
психологічного дискомфорту та \\
емоційного навантаження.
\end{tabular} & $\begin{array}{l}\text { Ліпка «Мій талісман». } \\
\text { Груповий колаж «Я в групі». } \\
\text { Вправа «Емоції в спілкуванні». } \\
\text { Релаксаційна вправа «Храм тиші». } \\
\text { Обговорення учасниками отриманого на занятті } \\
\text { досвіду. } \\
\text { Домашнє завдання. }\end{array}$ \\
\hline \multicolumn{2}{|c|}{ Заняття 11. Конструктивний вплив на чужі емоиії } \\
\hline $\begin{array}{l}\text { Вміння побачити себе збоку та } \\
\text { усвідомлення «відбитку» власної } \\
\text { психічної реальності; розкриття } \\
\text { власних проекцій внутрішнього } \\
\text { світу, дотично репрезентованих у } \\
\text { символах малюнків. }\end{array}$ & $\begin{array}{l}\text { Вступне слово. } \\
\text { Вправи для згуртування групи та розвитку } \\
\text { емоційно-вольової сфери. } \\
\text { Очікування. } \\
\text { Міні-лекція «Конструктивний вплив на чужі } \\
\text { емоції». } \\
\text { Мандала «Моя країна почуттів». } \\
\text { Вправа «Прийняття емоцій інших». } \\
\text { Гра «Відтвори голос». } \\
\text { Музична вправа. } \\
\text { Обговорення учасниками отриманого на занятті } \\
\text { досвіду. } \\
\text { Домашнє завдання. }\end{array}$ \\
\hline \multicolumn{2}{|c|}{ Заняття 12. Конструктивний вплив на чужі емоиії } \\
\hline $\begin{array}{l}\text { Набуття } \\
\text { сприичок }\end{array}$ & $\begin{array}{l}\text { Вступне слово. } \\
\text { Вправи для згуртування групи та розвитку } \\
\text { емоційно-вольової сфери. } \\
\text { Очікування. } \\
\text { Міні-лекція «Конструктивний вплив на чужі } \\
\text { емоції». } \\
\text { Мандала (за Ізабель Мюллєр). } \\
\text { Вправа «Комплімент». } \\
\text { Вправа «Вислухай і поверни». } \\
\text { Групова казка. } \\
\text { Обговорення учасниками отриманого на занятті } \\
\text { досвіду. Домашнє завдання. }\end{array}$ \\
\hline \multicolumn{2}{|c|}{ Заняття 13. Емпатія та емпатійне висловлювання } \\
\hline $\begin{array}{l}\text { Розвиток взаємної підтримки та } \\
\text { вміння ділитись своїми почуттями; } \\
\text { створення умов для трансформації } \\
\text { образу «Я» через дотик до матеріалу. } \\
\text { Розвиток емпатійного слухання, } \\
\text { урахування емоційного стану інших } \\
\text { у взаємодії. } \\
\text { Підвищення рівня згуртованості } \\
\text { групи. }\end{array}$ & 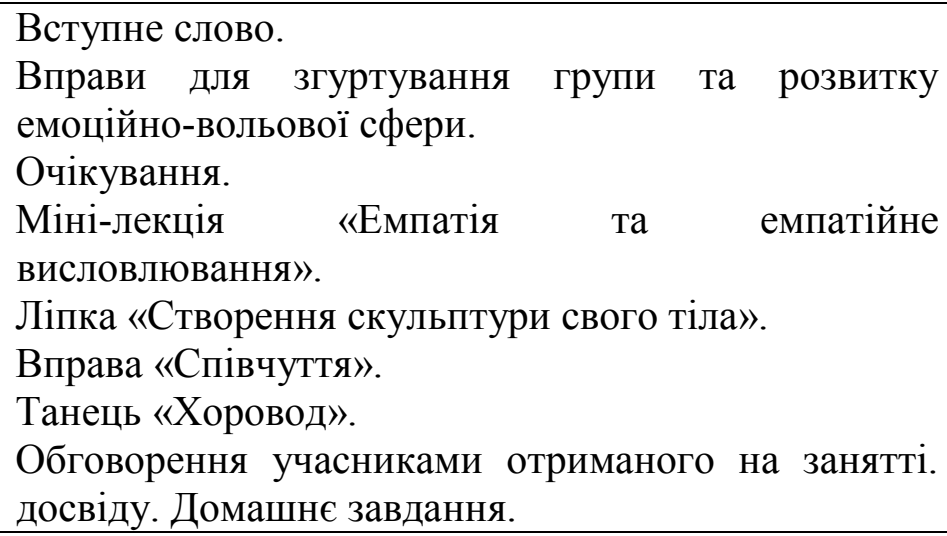 \\
\hline
\end{tabular}




\begin{tabular}{|c|c|}
\hline 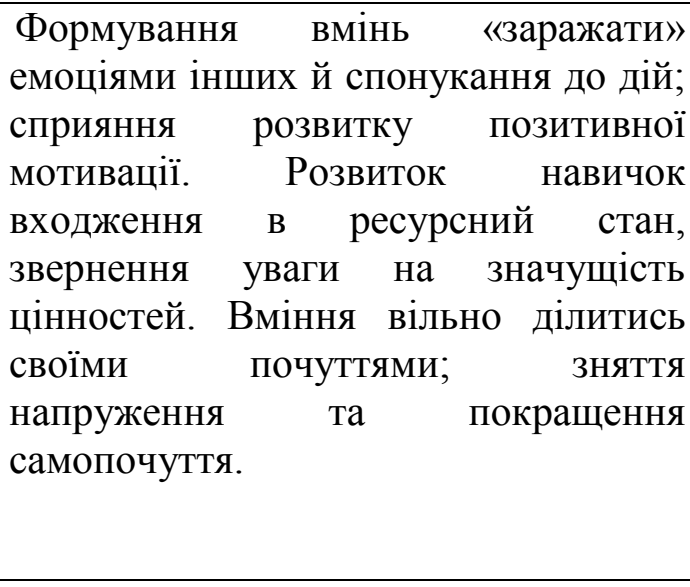 & 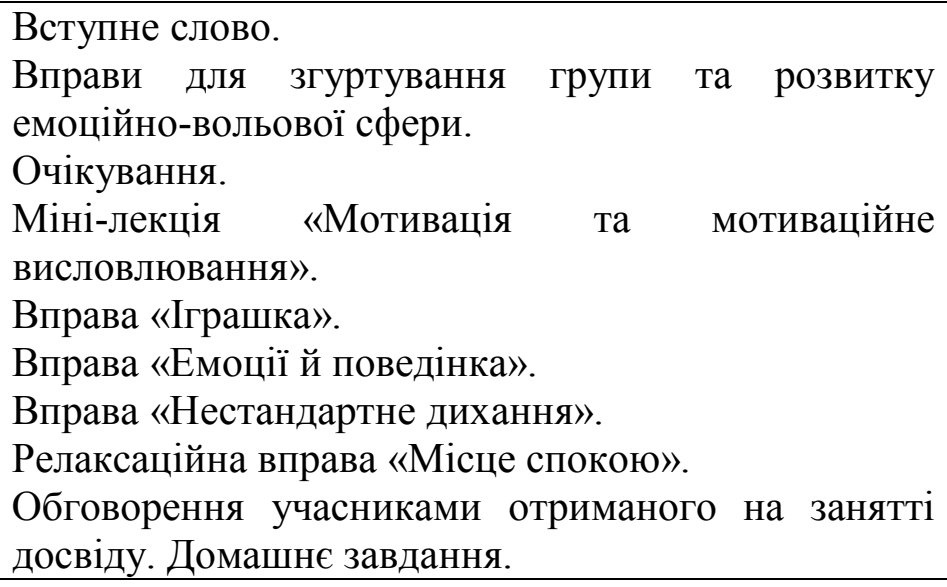 \\
\hline \multicolumn{2}{|c|}{ Заняття 15. Мій світ емоизій } \\
\hline 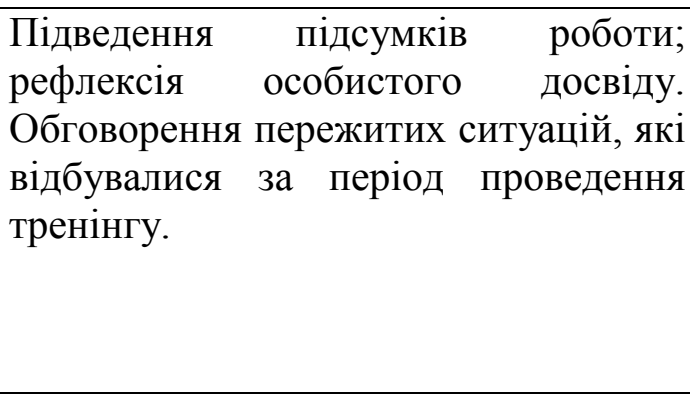 & $\begin{array}{l}\text { Вступне слово. } \\
\text { Вправа на розвиток саморефлексії. } \\
\text { Аналіз життєвих ситуацій. } \\
\text { Вправи для створення позитивного емоційного } \\
\text { фону. Оцінка ефективності тренінгу. } \\
\text { Обговорення учасниками отриманого на занятті } \\
\text { досвіду. Психологічний супровід особистості } \\
\text { школяра }\end{array}$ \\
\hline
\end{tabular}

Тренінгом було охоплено 20 учнів старших класів (11 клас), які склали експериментальну групу і 20 учнів старших класів (11 клас), які склали контрольну групу. Контрольна група слугувала як порівняльний зріз (як група, де не здійснювався формувальний вплив), із експериментальною групою, де і була застосована формувально-експериментальна програма.

Перед тренінгом було проведено констатувальний зріз, а після його завершення контрольний замір з метою вивчення міри впливу незалежної змінної на залежну. Для визначення статистичної значущості динаміки експериментальної та контрольної груп до і після формувального впливу був застосований $t$ - критерій Стьюдента. Аналітичне узагальнення результатів формувального експерименту дозволяє констатувати позитивну динаміку розвитку емоційного інтелекту досліджуваних у експериментальній групі. Переконливим підтвердженням результатів кількісного аналізу стали якісні зміни, виявлені в цій групі, що незаперечно засвідчило ефективність експериментального впливу.

Відтак ми вивели узагальнені результати показників емоційного інтелекту (методика «емоційного інтелекту» Н. Холла) експериментальної і контрольної груп до i після експериментального впливу (див. табл.2).

Таблиия 2

\section{Динаміка показників емоційного інтелекту до і після формувального впливу (експериментальна та контрольна групи)}

\begin{tabular}{|c|c|c|c|c|}
\hline \multirow[b]{2}{*}{$\begin{array}{c}\text { Рівні емоційного } \\
\text { інтелекту }\end{array}$} & \multicolumn{2}{|c|}{ Експериментальна група } & \multicolumn{2}{|c|}{ Контрольна група } \\
\hline & $\begin{array}{c}\text { до } \\
\text { експерименту } \\
(y \%)\end{array}$ & $\begin{array}{c}\text { після } \\
\text { експерименту } \\
(\text { у \%) }\end{array}$ & $\begin{array}{c}\text { до } \\
\text { експерименту } \\
\text { (у \%) }\end{array}$ & $\begin{array}{c}\text { після } \\
\text { експерименту } \\
\text { (у \%) }\end{array}$ \\
\hline низький & 90 & 20 & 80 & 80 \\
\hline середній & 10 & 70 & 20 & 20 \\
\hline високий & 0 & 10 & 0 & 0 \\
\hline $\begin{array}{l}\text { статистика } \\
\text { (T-test) }\end{array}$ & \multicolumn{2}{|c|}{$-7,11356$, при $\mathrm{p} \leq 0,05$} & \multicolumn{2}{|c|}{ 0,297902, при $\mathrm{p} \leq 0,05$} \\
\hline
\end{tabular}


Результати формувального експерименту дають підстави констатувати валідність, ефективність й перспективність щодо подальшого застосування розробленої та експериментально апробованої нами розвивальної програми. Головний результат іiї апробації полягає в тому, що досліджувані експериментальної групи спромоглись розвинути свій емоційний інтелект у процесі функціонального пов'язування арт-терапевтичного самовираження своїх проблемних дихотомій «хочу-маю», «прагну-можу» завдяки використанню художньо символічних образів і форм та аксіологічного осмислення їх емоційного змісту, скерованого на досягнення бажаного.

Таким чином, у старшокласників розвивається здатність мисленнєво регулювати емоційну складову проблем, тобто, власне емоційний інтелект.

Висновки. Підсумовуючи, стверджуємо: арт-терапевтичні психомалюнки, колажі і казки являють собою оптимальні засоби образно символічного вираження, а відтак рефлексивного осмислення суб'єктом своїх проблемних дихотомій «хочу - маю», «прагну - можу» 3 акцентуванням уваги на емоційному змісті цих дихотомій. Слухання музики і співи, ліпка 3 пластиліну, психогімнастика, танці медитації як засоби арт-терапії, відповідні тренінгові техніки слугували емоційній релаксації, зняттю емоційного i соматичного напруження, створенню оптимального емоційного стану досліджуваних і налаштування учасників.

Відповідні вправи спрямовані на розвиток обізнаності у царині емоцій, емпатії, здатності конструктивно впливати на емоційні переживання учасників, формування вмінь і навичок комунікативно компетентної експресії власних емоцій та керування ними. Характер спілкування у арт-терапевтичних групах, а саме дискусійне обговорення рефлексованого осмислення емоційно забарвлених проблем учасників $\epsilon$ сприятливим комунікативним середовищем, щодо розвитку емоційного інтелекту. Обговорення зображувальної продукції та інших аспектів арт-терапевтичного процесу сприяє особистості старшокласника усвідомити зміст свого внутрішнього емоційного світу, його зв'язок із власними емоційними реакціями та емоційною обізнаністю щодо проявів емоційної складової інших, настанов та мотивів їхніх емоційних реакцій, а відтак, розвивати уміння конструктивного емоційного відреагування.

Отже, ефективний розвиток емоційного інтелекту старшокласників засобами арт-терапії сприяє оптимізації їхнього світоглядно-диспозиційного самовизначення.

Перспективність подальших наукових пошуків вбачаємо у розробці інноваційної психотехнології розвитку EQ молодших школярів, підлітків та старшокласників на основі нашої програми «Розвиток емоційного інтелекту старшокласників засобами арт-терапії».

\section{СПИСОК ПОСИЛАНЬ}

Бабенко, К. А. (2007). Взаємозвязок механізмів символізації несвідомого (на матеріалі психоаналізу комплексу тематичних психомалюнків). (Автореф. дис. канд. психол. наук). Інститут психології ім. Г. С. Костюка АПН України, Київ.

Божович, Л. И., \& Благонадежина, Л. В. (1972). Изучение мотиваџии поведения детей $u$ подростков. Москва: Педагогика.

Вайбах, Х., \& Дакс, У. (1998). Эмочиональный интеллект. Москва.

Грегг, М. Ферс. (2003). Тайный мир рисунка. Санкт-Петербург: Деметра.

Дэвидсон, Р., \& Бегли, Ш. (2012). Как эмоции управляют мозгом. Измените свои эмоции и вы измените свою жизнь. Санкт-Петербург: Питер.

Калошин, В. Ф., Безносюк, О. О., \& Лемешко, Ю. П. (2006). Вплив емоцій на ефективність навчального процесу. Практична психологія та соиіальна робота, 1, 70-74.

Копытин, А. И. (2005). Диагностика в арт-терапии. Метод “Мандала”. Санкт-Петербург: Речь.

Конопкин, О. А. (2006). Участие эмоций в сознательной регуляции целенаправленной активности человека. Вопросы психологии, 3, 38-48.

Либин, А. В. (2000). Дифференциильная психология: на пересечении европейских, российских и американских традиций. Москва: Смысл.

Москалець, В. П. (2014). Сутність інтелекту, мислення, мовлення, свідомості як психофункціональних данностей. Психологія і суспільство, 4, 114-131.

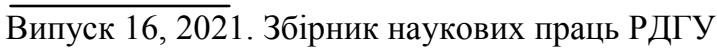


Опанасюк, I. В. (2014). Взаємозв'язок емоційного інтелекту та пізнавальних процесів у старшому шкільному віці. Збірник наукових пращь: філософія, соціологія, психологія, $19,2$.

Опанасюк, I. В. (2015). Вплив засобів арт-терапії на розвиток емоційного інтелекту старшокласників. Гуманітарний вісник ДВНЗ “Переяслав-Хмельнииький державний педагогічний університет імені Григорія Сковороди”. Міжнародні Челпанівські психолого-педагогічні читання, 35, I (13), 269-275.

Опанасюк, I. В. (2015). Психодіагностика розвитку емоційного інтелекту особистості в старшому шкільному віці. Вісник Дніпропетровського університету. Психологія, 21, 94-103.

Остер, Дж., \& Гоулд, П. (2000). Рисунок в психотерапии. Москва: Прогресс.

Саенко, Ю. В. (2010). Техники и приемы регуляции эмоций. Вопросы психологии, 3, 83-93.

Степанов, О. М. (2006). Психологічна енциклопедія. Київ: Академвидав.

Терлецька, Л. (2007). Психокорекція засобами малюнку. Київ: Главник.

Чернуха, I. О. (2010). Психокорекиія особистості засобами арт-терапіï. (Автореф. дис. канд. психол. наук). Волинський національний університет ім. Лесі Українки, Луцьк.

Яценко, Т., \& Теслюк, П. (2005). Особливості застосування малюнкових методик у роботі групи АСПН та у практиці онтопсихологічного дослідження: контури порівняльного аналізу. Психологія і суспільство, 4, 131-135.

\section{REFERENCES}

Babenko, K. A. (2007). Vzaiemozviazok mekhanizmiv symvolizatsii nesvidomoho (na materiali psykhoanalizu kompleksu tematychnykh psykhomaliunkiv) [Interrelation of mechanisms of symbolization of the unconscious (on the material of psychoanalysis of a complex of thematic psychomrawings)]. (Avtoref. dys. kand. psykhol. nauk). Instytut psykholohii im. H. S. Kostiuka APN Ukrainy, Kyiv. [in Ukrainian].

Bozhovych, L. I. \& Blagonadezhina, L. V. (1972). Izucheniye motivatsii povedeniya detey $i$ podrostkov [Studying the motivation of behavior in children and adolescents]. Moskva: Pedagogika. [in Russian].

Vaybah, H., \& Daks U. (1998). Emotsionalnyiy intellekt [Emotional intelligence]. Moskva. [in Russian].

Gregg, M. Fers (2003). Taynyiy mir risunka : perevod s angl [The secret world of drawing]. SanktPeterburh: Demetra. [in Russian].

Devidson, R., \& Begli, Sh. (2012). Kak emotsii upravlyayut mozgom. Izmenite svoi emotsii i vy izmenite svoyu zhizn [How emotions control the brain. Change your emotions and you change your life]. Sankt-Peterburh: Piter. [in Russian].

Kaloshyn, V. F., Beznosiuk, O. O., \& Lemeshko Yu. P. (2006). Vplyv emotsii na efektyvnist navchalnoho protsesu [The influence of emotions on the effectiveness of the educational process]. Praktychna psykholohiia ta sotsialna robota, 1, 70-74. [in Ukrainian].

Kopytin, A. I. (2005). Diagnostika v art-terapii. Metod "Mandala"[Diagnostics in art therapy. Mandala method]. Sankt-Peterburh: Rech. [in Russian].

Konopkin, O. A. (2006). Uchastiye emotsiy v soznatelnoy regulyatsii tselenapravlennoy aktivnosti cheloveka [Participation of emotions in the conscious regulation of purposeful human activity]. Voprosy psikhologii, 3, 38-48. [in Russian].

Libin, A. V. (2000). Differentsialnaya psikhologiya: na peresechenii evropeyskikh, rossiyskikh $i$ amerikanskikh traditsiy [Differential psychology: at the intersection of European, Russian and American traditions]. Moskva: Smysl. [in Russian].

Moskalets, V. P. (2014). Sutnist intelektu, myslennia, movlennia, svidomosti yak psykhofunktsionalnykh dannostei [The essence of intelligence, thinking, speech, consciousness as psychofunctional data]. Psykholohiia i suspilstvo, 4, 114-131. [in Ukrainian].

Opanasiuk, I. V. (2014). Vzaiemozviazok emotsiinoho intelektu ta piznavalnykh protsesiv u starshomu shkilnomu vitsi [Relationship between emotional intelligence and cognitive processes in high school age]. Zbirnyk naukovykh prats: filosofiia, sotsiolohiia, psykholohiia, 19, 2. [in Ukrainian]. 
Opanasiuk, I. V. (2015). Vplyv zasobiv art-terapii na rozvytok emotsiinoho intelektu starshchoklasnykiv [The influence of art therapy on the development of emotional intelligence of high school students]. Humanitarnyi visnyk DVNZ "Pereiaslav-Khmelnytskyi derzhavnyi pedahohichnyi universytet imeni Hryhoriia Skovorody”. Thematic issue International Chelpanovsky psychological and pedagogical readings in English, 35, 1 (13). [in Ukrainian].

Oster, Dzh., \& Gould, P, (2000). Risunok v psikhoterapii [Drawing in psychotherapy]. Moskva: Progress. [in Russian].

Sayenko, Yu.V. (2010). Tekhniki i priyemy regulyatsii emotsiy [Emotion regulation techniques and tricks]. Voprosy psikhologii, 3, 83-93. [in Russian].

Stepanov, O. M. (2006). Psykholohichna entsyklopediia [Psychological encyclopedia]. Kyiv : Akademvydav. [in Ukrainian].

Terletska, L. (2007). Psykhokorektsiia zasobamy maliunku [Psychocorrection by means of drawing]. Kyiv: Hlavnyk. [in Ukrainian].

Chernukha, I. O. (2010). Psykhokorektsiia osobystosti zasobamy art-terapii [Psychocorrection of personality by means of art therapy]. (Avtoref. dys. kand. psykhol. nauk). Volynskyi natsionalnyi universytet im. Lesi Ukrainky, Lutsk. [in Ukrainian].

Yatsenko, T., \& Tesliuk, P. (2005). Osoblyvosti zastosuvannia maliunkovykh metodyk u roboti hrupy ASPN ta u praktytsi ontopsykholohichnoho doslidzhennia: kontury porivnialnoho analizu [Features of application of drawing techniques in work of group ASPN and in practice of ontopsychological research: contours of the comparative analysis]. Psykholohiia $i$ suspilstvo, 4, 131-135. [in Ukrainian].

\title{
THE ART - THERAPY PROGRAM OF DEVELOPING EMOTIONAL INTELLIGENCE OF THE HIGH SCHOOL STUDENTS
}

\author{
Iruna Opanasyuk \\ Candidate of Psychological Sciences, psychologist \\ Ivan Franko Lyceum №12 Ivano-Frankivsk \\ https://orcid.org/0000-0003-3626-0691
}

DOI https://doi.org/10.35619/praprv.v1i16.222

The article presented the program of the development of the emotional intelligence of high school students of the art therapy and auxiliary means, directs at the reflective analysis of the emotional content of the worldview and disposition research, which are expressed by the symbolic forms of the art therapy and other expressive and interactive means and the results of the experimental researches regarding the proposed program are shown. The concepts of the emotional intelligence and its development, particularly concerning high school students are given a theoretical analysis. The main psychological content of the notion "emotional intelligence" and the development potential of the art therapy in the emotional intelligence of the personality have been analytically researched. The thesis gives the psychological and pedagogical basis of the emotional intelligence development of high school students by means of art therapy. The methodological background, the procedure and results of the empirical component of the research aiming at diagnosing the characteristics of emotional intelligence and forming the empirical basis of the forming experiment have been stated. The results of the forming experiment certified its validity and effectiveness. They aim the development of the ability to solve the emotional component of the problem, i.e. emotional intelligence

Key words: high school students, emotional intelligence, emotional experience, art-therapy, symbolic self-expression, reflection upon the problematic dichotomy «want-can». 